TOMORI TÍMEA

\title{
A KOGNITÍV KOMMUNIKÁCIÓS KOMPETENCIA TANTERVI VIZSGÁLATA A GIMNÁZIUM 9-10. ÉVFOLYAMÁN
}

\begin{abstract}
Absztrakt
A tanulmány a kommunikációs kompetencia és az információs műveltség kérdését iskolapedagógiai megközelítésbe helyezi. A kompetenciaelméletek közül a vizsgálat Nagy József személyiségfelfogására támaszkodik. A személyiséget alkotó kognitív, személyes, szociális és speciális kompetenciák közül a kognitív kompetencia kerül a vizsgálódás középpontjába. A vizsgálat módszere dokumentumelemzés. A vizsgálat tárgya a NAT (2012) és a gimnáziumi (9-10. évfolyamos) kerettanterv. A vizsgálatban a Szőke-Milinte Enikő (2012) által alkotott komponenskészlet adja a kódolási rendszert. A vizsgálat során négy jól elkülöníthető csoport jött létre. 1. Azok a kódok, amelyek nem jelentek meg a vizsgált dokumentumokban. 2. Számosságát tekintve nem érte el a dokumentumban a gyakorisági mutató a tízet. 3. Számosságát tekintve a gyakorisági mutató tíz és száz között volt. 4. A jelentős mértékben megmutatkozó kódok kerültek ebbe a csoportba, tehát azok, amelyek több mint százszor fordultak elő a vizsgált dokumentumban. A vizsgálat eredménye megmutatja, hogy mire helyezi a hangsúlyt az előírás; tehát hogy a tanulóknak a fejlődését milyen területeken szorgalmazzák a szabályozó dokumentumok. Ennek a kutatásnak a folytatása pedig arra fog rámutatni, hogy az intézményekben ezek az előírások milyen mértékben tarthatóak, illetve milyen módszerekkel dolgoznak azok a pedagógusok, akik a kommunikációs kompetenciafejlesztésben részt vesznek.
\end{abstract}

Kulcsszavak: kognitív kommunikációs kompetencia, információs műveltség, szabályozó dokumentumok 


\section{Elméleti háttér}

A kognitív pedagógiát Csapó $(1992,38)$ szerint „sajátos kapcsolatrendszer által összerendezett problémahálónak tekinthetjük, melynek elemei más diszciplínához is tartoznak”. Rámutat arra, hogy a kognitív jelenségeket még a pszichológia tudósai sem tudják precízen elválasztani egymástól. Csapó alapvetően a „megismeréssel, a gondolkodással, az értelmi fejlődéssel és az információfeldolgozással összefüggő jelenségeket” sorolja ide (Csapó, 1992, 39). Réthyné $(2001,155)$ folytatja a gondolatsort azzal, hogy „a tanulás és a tapasztalás a motivációban összekapcsolódik és fordítva [...] A motiváció fejlődése a gyermeknél nem elválasztható a kognitív fejlődéstől, két egymással interaktív kapcsolatban álló mechanizmusról van ugyanis szó." (Réthyné, 2001, 055) Józsa Krisztián A képességek és motívumok kölcsönös fejlesztésének lehetősége című tanulmányában kifejti, hogy a motivációkutatás trendjébe illeszthető Nagy József személyiségelmélete is. Nagy József személyiségfelfogáában az ember személyiségét a motívumok és a képességek struktúrájaként determinálja. (Nagy, 2007, 27) Az értelemnek három funkcióját különíti el, így a személyiség egyik alrendszerének nevezi, továbbá hozzáteszi, hogy „a túlélésben, az életminőség megőrzésében” jut fontos szerephez, illetve az információkezelésben is kiemelkedő fontosságú. (Nagy, 2000, 68) Ehhez szorosan kapcsolódik Hulyák-Tomesz Tímea gondolata, miszerint „boldogulásunk fokmérője lett kommunikációs hatékonyságunk”. (Hulyák-Tomesz, 2017, 39) „Az ember kognitív kompetenciája információkezelő komponensrendszer, amely információk felvételével, új ismeretek, tudás létrehozásával és önmaga módosulásával, fejlődésével szolgálja az ember, a csoport, a társadalom, a faj túlélését, életminőségének megőrzését és javítását." (Nagy, 2000, 69) A kommunikációs kompetencia fejlesztésének szempontjából hangsúlyossá válik tehát a harmadik, információs tudással kapcsolatos funkció. Az információs társadalom középpontjában az információk állnak és az, hogy az egyén milyen módon, milyen típusú információkat képes megszerezni, továbbá milyen mértékben képes a hatékony kommunikációra. Gurbán és mtsai. (2012) négy fontos tényezőben látják az információs társadalom lényegét. Ezek közül kiemelendő a pedagógia szempontjából a második, amely szerint „az információ, a kutatás, a fejlesztés önálló értékké válik”. Ugyanakkor az Országos Pedagógiai Könyvtár és Múzeum (OPKM) jelentős munkája, az Információs Mủveltség és Oktatásügy (2006) (a továbbiakban ImOK) megközelítése szerint modern világunkban az információs műveltség képességkomponenseinek fejlesztése már alapvető feladata az oktatóknak, pedagógusoknak is. Ennek terepet kell hogy biztosítson az általános és a középiskola, valamint a felsőoktatási intézmények egyaránt. Az ImOK című kiadványban részletes leírást is találunk ennek módszereiről és a korcsoportonkénti kívánatos tudásszintről. Az ALA (American Library Assotiation) meghatározását használva olyan képességekre fókuszálnak, mint hogy az egyén (itt tanuló) képes a saját érdeklődésének, 
információigényének a felismerésére, „képes azonosítani, megtalálni, értékelni, rendszerezni, hatékonyan létrehozni és felhasználni, majd kommunikálni az információkat egy kérdés, vagy egy probléma megoldása érdekében”. (Csík, 2006, 12) Ezek a képességkomponensek, valamint a kognitív kommunikációs kompetencia képességkomponensei egymásba érnek. Mivel Nagy József személyiségfelfogása, rendszerszemlélete kiváltképp alkalmas a kommunikációs kompetencia kérdéseinek vizsgálatára, így az ő elméletét továbbgondoló Szöke-Milinte Enikö komponenskészletét tartottam a vizsgálat szempontjából relevánsnak, ebből indultam ki. A kutatási anyagomban pedig a dokumentumok elemzésekor a fent említett komponenskészletet vizsgáltam.

\section{A kognitív kommunikációs kompetencia komponenskészletének megjelenése a tantervekben}

A vizsgálódás módszerét a dokumentumelemzés adta. A vizsgálat anyaga a Nemzeti alaptanterv és az általános képzést nyújtó gimnáziumi kerettanterv 9. és 10. évfolyamos elöírásai voltak. A 9-10. évfolyam dokumentumainak vizsgálatát indokolja, hogy a középiskola második szakaszában, a 11. és 12. évfolyamon a gimnáziumokban a továbbtanulási szándéktól és specializációtól függően különböző tudományterületeket különböző óraszámokban tanulnak a közelgő felvételi eljárás miatt a diákok. Továbbá a NAT elemzése során a művészeti jellegű tanegységek és a magyar nyelv és irodalom terület emelkedett ki a kommunikációs kompetencia fejlesztésének vizsgálata alkalmával. A művészeti jellegű tantárgyak jelentősebb mértékben jelennek meg a 9-10. évfolyamon, valamint minden tanítási év májusában a 10. osztályos tanulók írnak országos kompetenciatesztet, ami szintén indokolja, hogy a 9-10. évfolyamon tanulók számára általánosabb jellegű képzés valósuljon meg.

A tanulmány célkitűzése, hogy a kognitív kommunikációs kompetencia tantervekben való megjelenését alaposan vizsgálja az általános képzésü gimnáziumok 9 és 10. évfolyamán. Az elemzés prototípusaként szolgált Szőke-Milinte Enikö A kommunikációs kompetencia a 2012-es NAT vitaanyagában című tanulmánya, amely már egyértelmüen meghatározta korábban a különböző kompetenciaterületek komponenskészleteit. Ennek köszönhetően a kognitív kommunikációs kompetencia komponenskészletén ebben az írásban a: kódolás, dekódolás, üzenet megfogalmazása, reflexió, értelmezés, felidézés elmondás, információgyüjtés, képzelet, kreativitás, kritikai gondolkodás - információk kritikus befogadása - forráskritika, megértés, elemzés, lényegkiemelés, tömörités, összefoglalás, felismerés - feltérképezés, alkalmazás, összehasonlitás, összevetés, azonositás, értékelés, feldolgozás, cselekmény felidézése, megfogalmazás, olvasás, elbeszélés, itéletalkotás tételeket értjük. 


\subsection{NAT}

A NAT elemzése műveltségterületenként történt, továbbá a műveltségterületeken túlra is kiterjedt. Ez a rész az adatok elemzésekor az általános (nem műveltségterületi) részek nevet kapta. A teljes NAT anyagát vizsgálva elmondható, hogy a kognitív kommunikációs kompetencia adatbázisa bizonyult a legkiterjedtebbnek, így az összes adat négy területre (kognitív, személyes, szociális és speciális) oszlik el, de annak a 70\%-a a kognitív területet érinti - ebből is érzékelhetjük a kognitív kommunikációs kompetenciaterület fontosságát. (1. ábra) A maradék harminc százaléknyi adat sem mutat egységes eloszlást, a szociális terület 16\%-ban, a személyes terület 10\%-ban, míg a speciális terület 4\%-ban jelenik meg az elemzett adatok sorában.

A kognitív kommunikációs kompetenciaterületre térve a kódonkénti elemzés bemutatása következik. A különböző kódok előfordulását tekintve mind számosságukban, mind arányaikban szignifikáns különbségek vannak. Előfordul néhány kód, ilyenek az üzenetek megfogalmazása, a reflexió, a cselekmény felidézése és az itéletalkotás, amelyek nem jelennek meg a tantervben egyik műveltségterületen sem. Ezeket nevezem az első csoportnak, hiszen nem szerepelnek a tantervben.

A második kategóriába sorolom a minimális, alig kimutatható itemeket. Ezek az alacsony számosságot mutató előfordulások. A kódolás például kizárólag a művészetek műveltségterületen egyetlen előfordulást mutat, míg a dekódolás a magyar nyelv és irodalom műveltségterületen jelent meg kétszer, azaz szintén jelentéktelen mértékben. Ugyanilyen mértékủ az információgyüjtés, a lényegkiemelés és a tömörités kódmennyisége is. Eloszlásuk szerint az információgyüjtéssel a magyar nyelv és irodalom, valamint az ember és társadalom műveltségterületen találkozhatunk. A lényegkiemelés itemet a magyar nyelv és irodalom műveltségterületen két kóddal, míg a matematika műveltségterületen egy kóddal szerepelteti a NAT. A tömörítés összesen két kóddal lelhető fel a dokumentumban, ezek ismételten a magyar nyelv és irodalom területén fordulnak elő. Ebbe a csoportba tartozik még a nyolc kóddal bíró képzelet, amelyből három kódot a magyar nyelv és irodalom műveltségterület tesz ki, négyet a matematika és a maradék egyet a művészetek. Az összefoglalás hét kódot számlál, de mind a hét kód a magyar nyelv és irodalom területén található.

A harmadik csoportba számosságukat tekintve jelentősebb találatok kerültek, de még nem kimagaslóak. Így itemenként számolva a tíztől magasabb, de száztól alacsonyabb találatú komponenseket soroltam ide. Eszerint tizenkét kódot számlál a kritikai gondolkodás. Eloszlását tekintve már a műveltségterületen kívül eső általános jellegủ leírásban is található egy kód, további négy a magyar nyelv és irodalom műveltségterületen, három az ember és társadalom műveltségterületen, kettő a művészetek műveltségterületen, egy 
az informatika és egy a testnevelés és sport területén is. A kreativitás tizenhárom kódja az általános jellegű leró részek (öt), a magyar nyelv és irodalom (három), a matematika (kettő), illetve a testnevelés és sport területei (három) között oszlik meg. Az elbeszélés tizenhat kódja nem mértékadóan oszlik meg, hiszen tizenhárom kódot számlál a magyar nyelv és irodalom műveltségterület, kettőt az ember és társadalom, egyet a művészetek. Az olvasás is csak tizenhét kódot tudhat magáénak. Megoszlása szerint: az általános jellegű, leíró részben egy, a magyar nyelv és irodalom területen hat, a matematika területén nyolc, a müvészetekben pedig két kódot számlálhatunk. Az azonositás huszonhét kódot számlál általános rész (1), magyar nyelv és irodalom (13), matematika (4), ember és társadalom és ember és természet (1-1), művészetek (5), életvitel és gyakorlat (2) eloszlásban. A felidézés - elmondás kategóriát harminc kóddal írhatjuk le. A matematika tizenkilenc kóddal, a magyar nyelv és irodalom hét kóddal, a müvészetek pedig négy kóddal van jelen ezen a területen. Az értékelés negyvenegy kódot számlál, amelyből tízet az általános jellegű leíró rész, nyolcat a magyar nyelv és irodalom, hatot a testnevelés és sport, négyet-négyet az ember és természet és a művészetek, hármat - hármat az idegen nyelv és az ember és társadalom, kettőt a földünk és környezetünk, egyet az életvitel és gyakorlat tud magáénak. A feldolgozás itemet vizsgálva 42 kódot találunk: általános rész (4), magyar nyelv és irodalom (6), idegen nyelv (1), ember és társadalom (6), ember és természet (1), földünk és környezetünk (2), művészetek (17), informatika (4), testnevelés és sport (1). A megfogalmazás komponens 45 kóddal és ilyen eloszlással bír: ember és társadalom (12), matematika (11), művészetek (9), informatika (5), ember és természet, valamint magyar nyelv és irodalom (3-3), illetve idegen nyelv és életvitel és gyakorlat (1-1). Az összehasonlitás - összevetés nevü komponens negyvenhat kódot számlál az alaptantervben. Az ember és természet tizennégy, a matematika és a művészetek tíz-tíz, az ember és társadalom öt, a magyar nyelv és irodalom három, az életvitel és gyakorlat, valamint a testnevelés és sport egy-egy gyakoriságot mutat, de az általános leíró részben is szerepel kétszer. Végül az elemzés hatvankilences gyakoriságot mutat a dokumentumban. Műveltségterületenkénti megoszlása szerint: művészetek (27), ember és természet (22), magyar nyelv és irodalom (9), általános rész és életvitel és gyakorlat (3-3), ember és társadalom (2), idegen nyelv - matematika - földünk és környezetünk (1-1-1) arányban jelenik meg.

A negyedik kategóriába soroltam azokat a komponenseket (értelmezés, megértés, felismerés - feltérképezés, alkalmazás), amelyek számosságukat tekintve rendkívül erőteljesen, több mint száz kóddal jelentek meg a vizsgált dokumentumban. Ezek a komponensek az elemzési egységünk majdnem minden területén kiemelkedtek. Az alkalmazás százöt kódolással a leggyengébb elem közülük. Eloszlása szerint az alábbi arányban mutatkozik meg a komponens: ember és természet (24), testnevelés és sport (19), magyar nyelv és irodalom, valamint általános leíró részek (15-15), matematika (14), informatika (10), 
idegen nyelv (3), ember és társadalom és életvitel és gyakorlat (2-2), földünk és környezetünk (1). A megértés százhat kódolással szintén relevánsan mutatkozik meg az elemzett dokumentumban. Arányait tekintve magyar nyelv és irodalom (27), ember és természet (24), matematika (21), általános jellegű rész (12), művészetek (9), ember és társadalom (5), idegen nyelv (3), földünk és környezetünk - informatika (2-2), testnevelés és sport (1). A felismerés - feltérképezés komponensnek százötvenkettő kódolása van. Pontos megoszlását tekintve az ember és természet műveltségterületen található a kódolások egyharmada. (55) Földünk és környezetünk, (20) a magyar nyelv és irodalom, valamint a művészetek, (18-18) az ember és társadalom, (11) a matematika és az általános jellegű rész, (8-8) életvitel és gyakorlat, (5) testnevelés és sport - informatika - idegen nyelv (3-3-3) arányban oszlanak meg a műveltségterületenkénti kódok. Az értelmezés komponens mutatja a legmagasabb gyakoriságot százhetvennyolc előfordulással. Az ember és természet műveltségterület ismételten kiemelkedik lefedettség tekintetében a műveltségterületek közül (68) kóddal. A magyar nyelv és irodalom, valamint a matematika, (26-26) művészetek, (24) földünk és környezetünk, (12) ember és társadalom, (9) általános jellegủ rész, (8) testnevelés és sport, (3) informatika - idegen nyelv (1-1) arányt mutatott az elemzés alkalmával.

\subsection{Kerettanterv}

A kerettanterv az alaptantervet követő, arra épülő előíró, szabályozó dokumentum, amely kétévenkénti eloszlásban szabja meg azt, hogy a tanulóknak az adott tanulási ciklusban milyen tartalmakat kell elsajátítaniuk, és milyen jellegű kimeneti követelményeknek kell eleget tenniük. A kerettanterv órakeretének 10\%-ával a pedagógusok szabadon tervezhetnek, a többi előírás mindenkire nézve mértékadó. A középiskolák minden típusának külön kerettanterve van, így a gimnáziumoknak is létezik egy konkrétan az ő képzési sajátosságaikhoz igazodó, arra szabott tanterve. Mivel ez az alaptantervre épülő szabályozás, így nem lehetséges jelentős mértékü eltérés a két elemzési egység között. $\mathrm{Az}$ alaptantervet elemző részben részletes közlésre került minden egyes komponens műveltségterületenként. Ezzel a fejezettel az a célom, hogy összevessem a jelentős különbségeket (már van mivel összehasonlítani, a fenti adatsorhoz tudunk viszonyítani) az alaptanterv és a kerettanterv között. A kerettanterv különbözősége az alaptantervhez képest, hogy nem műveltségterületekben, hanem tantárgyakban "gondolkodik”. Továbbra is vannak a tantervnek olyan általános, leíró jellegű részei, amelyeket szükségesnek tartottam vizsgálni az adatok pontossága miatt, de ezek nem tartoznak a tantárgyi tartalmakhoz, így akárcsak az alaptantervben, itt is az általános részek kifejezést adtam neki.

Ismételten négy kategóriát tudtam felállítani. A négy kategória besorolása azonos az előzővel. Az első kategóriába a 9-10. évfolyamos gimnáziumi kerettantervben nulla 
kódot számláló komponensek kerültek. Ilyenek az üzenet megfogalmazása, az elemzés, a lényegkiemelés, a cselekmény felidézése. Már a kezdő kategóriánkban is vannak eltérések az alaptantervihez viszonyítva, de ezek nem relevánsak, egy vagy két kód különbségűek.

A második kategóriába szintén a viszonylag kevés kódot számláló komponensek kerültek. A kódolás, a dekódolás, a reflexió a kerettantervben ugyan megjelenik, de csak három kóddal; az információgyüjtés az előző kettőhöz képest már hét kódot számlál, de nem tud kategóriát lépni, a képzelet, a tömörités és az összefoglalás, feldolgozás tartoznak ebbe a kategóriába. Az itéletalkotás már jelen van, de csak két kód találatával. A számadatok természetesen nem mutatnak 100\%-os egyezést, csak hasonlóságokat. Mivel a kerettantervnek csak az első két évfolyamára vetített elemzését vesszük most górcső alá, így nem is kell teljesen megegyeznie ezeknek a számadatoknak, hiszen a 11. és 12. évfolyamos kerettantervben is lesznek még kódok az egyes komponensekre. Ami enyhébb furcsaságot mutat, az az, amikor a kerettantervben megjelenő számadatok már az első két évfolyam dokumentumának elemzését követően is túlmutatnak az alapdokumentum számadatain, pedig az elemzési módszer azonos volt. (Például: kódolás, 1-3, vagy reflexió, 0-3) Mivel ezek nem számottevő különbségek (bár a reflexió például kategóriát lép ebben a megközelítésben), így nem tulajdonítok jelentőséget neki, ugyanakkor a kerettanterv második szakaszának (11-12. évfolyam) vizsgálatát követően érdemes lesz összevetni az adatok különbözőségét.

A harmadik csoportba az átlagosnak tekinthető tíz és száz közötti kódot számláló komponensek kerültek ismételten. A kreativitás, az azonositás és az elbeszélés minimális különbségpontokat mutatott. Vannak azonban jelentékeny, számosságukat tekintve nagyobb változások is (bár ugyanebben a kategóriában maradva, de tíz-húsz kódnyi különbséget is mutatva), például a felidézés - elmondás, a kritikai gondolkodás, az összehasonlitás, az azonositás, értékelés, megfogalmazás és az olvasás.

A negyedik kategóriába ismét a legmagasabb kódszámot összegyűjtő komponensek kerültek. Összességében hasonló eredményre jutott ez az elemzési egység is, de az elemzés komponens kódszáma jelentősen megemelkedett, így felzárkózva az értelmezés, megértés, felismerés - feltérképezés és az alkalmazás komponensek mellé. Az elemzés komponens számosságát tekintve például a magyar nyelv és irodalom, valamint a történelem tantárgyaknál emelkedik meg, erre talán korrekt választ adhat az, hogy a tananyagok és az elvárt követelmények között ezek a tantárgyak rendkívül sok mü- és szövegelemzést, forráselemzést tartanak számon. Ezeknek az alapokhoz képest részletesebb leírása megemelheti a kódszámokat is.

Összességében ezek közül a komponensek közül az információs műveltséghez kapcsolhatóak az információgyüjtés, az alkalmazás, a felismerés, a kritikai gondolkodás, az értelmezés, a feldolgozás, a megfogalmazás/üzenet megfogalmazása. Amint látjuk, az információs 
műveltséghez jelentős mértékben kerültek olyan komponensek, amelyek a harmadik és a negyedik, azaz az erősen megjelenő komponensek közül valóak. Tulajdonképpen a negyedik, azaz a legintenzívebben megjelenő komponensek sorolhatóak ide, ami azt is mutatja, hogy a könyvtáros társadalom az iskolai életbe egy olyan fejlesztései területtel akar bekapcsolódni az információs műveltség fejlesztése kapcsán, amely valódi eredményeket hozhat a tanulók számára például az élethosszig tartó tanulás vagy akár a már többször emlegetett egyéni életben való boldogulásuk kapcsán.

\section{Konklúzió}

Tanulmányomban a kognitív kommunikációs kompetencia komponenskészletének vizsgálati eredményeit publikáltam a NAT 2012-es anyagát és a gimnáziumi kerettanterv 9. és 10. évfolyami anyagát vizsgálva. A vizsgálódásom módszere dokumentumelemzés volt. A NAT anyagából részletes adatokat közöltem, a kerettantervet pedig ezekhez hasonlítottam. Összességében még érdemesnek tartom megjegyezni azt, hogy a különböző műveltségterületeken (NAT), illetve tantárgyanként (kerettanterv) hogyan oszlanak meg a kódok.

A NAT-ban 924, míg a kerettantervben 1322 kód volt. Az általános rész a NAT-ban 70, a kerettantervben csak 22 kódot számlált. A NAT-ban továbbá a magyar nyelv és irodalom műveltségterületen 178, az idegen nyelvnél 16, a matematikánál 129, az ember és társadalomnál 62, az ember és természetnél 216, a földünk és környezetünknél 40, a művészeteknél 134, az informatikánál 26, az életvitel és gyakorlatnál 15, a testnevelés és sportnál 38 kód került meghatározásra. A kerettanterv tantárgyainál az alábbi számú kódnyi jelölés valósult meg: magyar nyelv és irodalom 248 , idegen nyelv 55 , matematika 108, történelem 103, biológia 39, fizika 126, kémia 117, földrajz 114, ének 24, vizuális kultúra 119, dráma 52, mozgóképkultúra 48, informatika 100, testnevelés és sport 47.

A NAT-ban az ember és természet műveltségterület emelkedik ki, a kerettanterv tantárgyainál pedig a magyar nyelv és irodalom került az első helyre. Ez első ránézésre talán disszonánsnak tűnik, de összességében kell tekintenünk az adatokra. Amennyiben minden (egyébként nagyon magas kódot számláló) természetismerethez kapcsolódó (földrajz, fizika, kémia, biológia) tantárgy kódját összeadjuk, úgy az már ismételten a magyar nyelv és irodalom fölé emelkedik számadataiban. Ami kérdéses, hogy bár az idegen nyelvi műveltségterület és tantárgy egyik kiemelkedő feladata a kommunikációs kompetencia fejlesztése, a szabályozó dokumentumokban mégsem rajzolódik ki ez a küldetés. A továbbiakban érdemes volna megvizsgálni azt, hogy akár a kognitív, akár a személyes, a szociális vagy a speciális kommunikációs kompetencia fejlesztése hogyan valósul meg az idegen nyelvi tantárgynál iskolapedagógiai környezetben. 
A kutatást és a dolgozat megjelenését az „EFOP-.3.6.1.-16-2016-00001-Kutatási kapacitások és szolgáltatások komplex fejlesztése az Eszterházy Károly Egyetemen" címü projekt támogatta.

\section{Irodalom}

Csapó B. (1992). Kognitiv pedagógia, Akadémiai Kiadó, Budapest.

Gurbán Á., Gurbán M., Hua Nm S. (2012). Információ, adat, intelligencia, Saldo Kiadó, Budapest.

Hulyák-Tomesz T. (2017). A kommunikációs készségfejlesztés feladatai a felsőoktatásban. In.: Szőke-Milinte Enikő (szerk.) A kommunikációs kompetencia fejlesztése a különbözö korcsoportokban, Hungarovox Kiadó, Budapest.

Józsa K. (2005). A képességek és motívumok kölcsönös fejlesztésének lehetősége. In.: Kelemen-Falus (szerk.) Tanulmányok a neveléstudomány köréböl, Műszaki Könyvkiadó, Budapest.

Nagy J. (2000). XXI. század és nevelés, Osiris Kiadó, Budapest.

Nagy J. (2007). Kompetenciaalapú kritériumorientált pedagógia, Mozaik Kiadó, Budapest. Réthy Endréné (2001) A tanulási motiváció elemzése. In.: Csapó Benő és Vidákovich Tibor (szerk.): Neveléstudomány az ezredfordulón: Tanulmányok Nagy József tiszteletére. Tankönyvkiadó, Budapest.

\section{Weboldalak}

Csík T. (2006). Információs müveltség és oktatásügy. OPKM, Budapest. http://www. opkm.hu/download/ImOk.pdf (letöltve: 2019. 12. 21.)

Szőke-Milinte Enikő (2012): A kommunikációs kompetencia a 2012-es NAT vitaanyagában. In.: Anyanyelv-pedagógia. 2012/2. szám. http://www.anyanyelv-pedagogia.hu/ cikkek.php?id=380 (letöltve: 2019. 12. 21.)

\section{Egyéb dokumentumok}

Kerettanterv a gimnáziumok 9-12. évfolyama számára. http://kerettanterv.ofi.hu/03_ melleklet_9-12/index_4_gimn.html (letöltve: 2019. 12. 11.)

NAT 2012. http://ofi.hu/sites/default/files/attachments/mk_nat_20121.pdf (letöltve: 2019. 12.08.) 


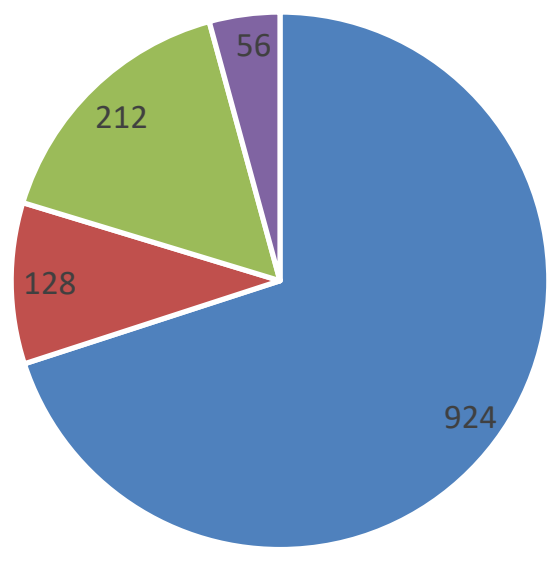

- Kognitív: - Személyes: - Szociális: - Speciális:

\section{1. ábra A NAT 2012-ben a kommunikációs kompetencia megoszlása} (saját feldolgozás, TT)

Név: Tomori Tímea

Munkahely: Nyíregyházi Egyetem

Beosztás/ foglalkozás: tanársegéd

e-mail: tomori.timea@nye.hu

Szakmai bemutatkozás: Tomori Tímea (1986) fôiskolai tanársegéd, a Nyíregyházi Egyetem Magyar Nyelvészeti Intézetének oktatója és az Eszterházy Károly Egyetem Neveléstudományi Doktori Iskolájának hallgatója iskolapedagógia specializáción. Okleveles magyartanár-kommunikációtanár és kommunikáció szakos bölcsész (újságíró, intézményi kommunikátor). A Kommunikációs Nevelésért Egyesület sajtóreferense. Érdeklődési köre és kutatási területe: tantervek és iskolapedagógia, a kommunikációs kompetencia fejlesztése a középiskolai korosztályban, az információs műveltség és az iskolapedagógia kapcsolata, anyanyelv-pedagógia - szakmódszertan. 